\title{
PENGEMBANGAN KURIKULUM BERBASIS MASYARAKAT DI SMP ALTERNATIF QARYAH THAYYIBAH SALATIGA JATENG
}

\section{Muchamad Solahudin}

Abstrak: Masyarakat memiliki peran dan tanggung jawab yang sangat besar dalam proses pengembangan kurikulum di satuan pendidikan mengingat sekolah adalah miniatur masyarakat yang kelak menjadi generasi penerus dalam melestarikan warisan budaya. Keterlibatan masyarakat dalam proses pengembangan kurikulum meliputi perumusan desain, perencanaan, pelaksanaan dan evaluasi kurikulum berbasis masyarakat. Fokus dalam tulisan ini meletakkan pola, konsep, strategi dan landasan masyarakat dalam perannya mengembangkan kuriukulum di sebuah sekolah alternatif. Sekolah alternatif memiliki latar belakang dan tujuan yang berbeda dengan sekolah konvensional sehingga memiliki karakteristik dan pola pengembangan yang berbeda pula. Meskipun demikian bentuk keterlibatan masyarakat dalam pengembangan kurikulum ini dapat dijadikan sebagai referensi bagi sekolah formal maupun nonformal lainnya.

Kata kunci: Pengembangan Kurikulum, Kurikulum Berbasis Masyarakat, Sekolah dan Pendidikan Alternatif 
ISSN: 1829-6750 Inovasi Kurikulum, Februari 2008, Thn. 5. Vol 5 Nomor: 1

\section{A. Pendahuluan}

Undang-Undang No. 20 tahun 2003 menyebutkan bahwa Pendidikan adalah usaha sadar dan terencana untuk mewujudkan suasana belajar dan proses pembelajaran agar peserta didik secara aktif mengembangkan potensi dirinya untuk memiliki kekuatan

spiritual keagamaan, pengendalian diri, kepribadian, kecerdasan, akhlak mulia, serta keterampilan yang diperlukan dirinya, masyarakat, bangsa dan negara. Dengan demikian, pendidikan nasional berfungsi mengembangkan kemampuan dan membentuk watak serta peradaban bangsa yang bermartabat dalam rangka mencerdaskan kehidupan bangsa, mengembangkan potensi peserta didik agar menjadi manusia yang beriman dan bertakwa kepada Tuhan Yang Maha Esa, berakhlak mulia, sehat, berilmu, cakap, kreatif, mandiri, dan menjadi warga negara yang demokratis serta bertanggung jawab. Untuk mencapai hal tersebut diperlukan adanya daya dukung yang maksimal dari seluruh pihak sesuai dengan peran dan tanggung jawab masing-masing.

Secara eksternal bisa kita amati bahwa tingkat pencapaian pendidikan kita belum memuaskan, masih banyaknya angka pengangguran akibat naiknya angka putus sekolah. Sampai tahun 2000, lebih dari enam juta anak usia sekolah yang tidak mampu menyelesaikan pendidikan tingkat dasar (Prasetyo: 2006: 7). Beberapa faktor penyebab meningkatnya angka putus sekolah diakibatkan oleh biaya persekolahan yang relatif mahal. Tidak semua orang tua mampu memenuhi biaya sekolah bagi anakanaknya. Dengan kata lain memunculkan adanya persepsi masyarakat bahwa pendidikan akan membawa 
ISSN: 1829-6750 Inovasi Kurikulum, Februari 2008, Thn. 5. Vol 5 Nomor: 1

implikasi pada meningkatnya biaya pendidikan. Hanya masyarakat yang memiliki harta lebih yang mampu meneruskan sekolah anakanaknya.

Adanya siswa yang tidak dapat menyelesaikan pendidikan dasar selama 9 tahun disebabkan oleh tiga kemungkinan. adanya siswa yang mengulang kelas. Siswa yang mengulang kelas memerlukan waktu yang lebih lama dari 9 tahun untuk menyelesaikan pendidikan dasar. Kedua, adanya siswa putus sekolah, baik di tingkat SD/MI maupun di SMP/MTs. Kalau siswa putus sekolah ini tidak ditampung pada lembaga pendidikan alternatif lainnya, maka mereka ini tidak akan menyelesaikan pendidikan dasar. Ketiga, adanya lulusan SD/MI atau yang setara yang tidak melanjutkan ke SMP/MTs atau yang setara. Jika lulusan tersebut tidak ditampung di lembaga pendidikan apapun termasuk pendidikan luar sekolah, maka mereka tidak akan dapat menyelesaikan pendidikan dasar. Mereka yang tidak mampu menyelesaikan pendidikan dasar, terutama yang terjadi di tingkat SD/MI merupakan faktor potensial untuk menjadi warga buta aksara, yang akan menjadi beban sosial di kemudian hari (Diknas: 2006: 26-27).

Sementara itu, dalam proses pembelajaran di sekolah lebih menekankan pada konteks pengajaran, transisi, dan transmisi, bukan transformasi. Siswa seringkali dipandang oleh guru sebagai botol kosong yang tidak memiliki apa-apa, datang ke sekolah untuk diisi air. Padahal dalam diri siswa memiliki, bakat, minat dan karakteristik yang perlu digali dan dikembangkan menjadi manusia yang seutuhnya melalui proses pendidikan yang wajar. 
ISSN: 1829-6750 Inovasi Kurikulum, Februari 2008, Thn. 5. Vol 5 Nomor: 1

Akibat dari kontrol guru yang rendah terhadap minat dan kebutuhan siswa berakibat pada lemahnya motivasi siswa dalam belajar. Hampir terjadi di banyak tempat, administrasi dan birokrasi, dipandang sebagai agenda yang lebih penting dan utama dari pada implementasi kurikulum. Pihak sekolah seringkali mengambil kebijakan yang bersifat kaku dan tunggal karena tata aturan yang harus dipatuhi secara struktural.

Sekolah sebagai tempat berinteraksi bukan hanya menjadi milik guru, siswa dan pemerintah. Tetapi lebih dari itu, di mana masyarakat harus terlibat aktif dalam pengembangan kurikulum, mengingat sekolah adalah miniatur masyarakat. Sering kita amati banyaknya masyarakat yang cenderung apatis terhadap sekolah. Masyarakat, dalam hal ini orang tua / wali murid, sering kali terlibat perannya di sekolah hanya pada saat membahas

biaya

persekolahan anaknya.

Banyak masyarakat yang menganggap dirinya telah menunaikan kewajibannya bila telah memenuhi persyaratan pembiayaan belajar anaknya di sekolah.

Dalam Kurikulum Tingkat Satuan Pendidikan telah dirumuskan bahwa tujuan pendidikan dasar adalah meletakkan dasar kecerdasan, pengetahuan, kepribadian, akhlak mulia, serta keterampilan untuk hidup mandiri dan mengikuti pendidikan lebih lanjut. Sementara itu, seperti yang telah diungkapkan di atas bahwa dengan masih banyaknya angka pengangguran dan putus sekolah tersebut, mengantarkan kita untuk berpikir lebih jauh lagi tentang pendidikan Indonesia ke depan.

Selanjutnya, menurut Djohar (Kompas : 2006 : 150-151) beberapa kelemahan sistem pendidikan kita saat ini dapat 
ISSN: 1829-6750 Inovasi Kurikulum, Februari 2008, Thn. 5. Vol 5 Nomor: 1

dikategorikan menjadi beberapa kelompok besar, antara lain ialah:

1. Lingkungan kita belum mendidik

2. Pendidikan kita belum memperhatikan ciri anak

3. Siswa dibebani biaya pendidikan

4. Belum ada integrasi sistem pendidikan antara pendidikan informal, nonformal dan formal.

5. Pendidikan kita cenderung diskriminatif.

6. Pembelajaran kita masih konvensional.

7. Pengajaran kita, belum memiliki muatan pendidikan.

8. Pola pendidikan kita belum mengarah kepada strategi membangun budaya.

9. Pendidikan kita belum menyenangkan siswa, belum memerdekakan bahkan

terasa

membelenggu.

10. Belum terjadi proses pembelajaran yang bermakna.

11. Pendidikan kita didominasi oleh kegiatan mengajar.

12. Pendidikan kita cenderung berorientasi kepada intelektualitas.

13. Kita belum melakukan evaluasi hasil pendidikan.

14. Pendidikan kita dijangka jauh harus mengintegrasikan antara ilmu dan agama yang keduanya untuk keselamatan manusia pada umumnya.

Selanjutnya dalam UU Sisdiknas kita telah menjelaskan bahwa setiap warga negara mempunyai hak yang sama untuk memperoleh pendidikan yang bermutu dan mendapat kesempatan meningkatkan pendidikan sepanjang hayat. Selain itu, masyarakat banyak berperan 
ISSN: 1829-6750 Inovasi Kurikulum, Februari 2008, Thn. 5. Vol 5 Nomor: 1

serta dalam perencanaan, pelaksanaan, pengawasan dan evaluasi program pendidikan. Masyarakat berkewajiban memberikan dukungan sumber daya dalam penyelenggaraan pendidikan.

Respon atas kondisi pendidikan di atas pada akhirnya melahirkan gagasan dari berabagi pihak untuk menyelenggarakan

persekolahan, pendidikan dan pembelajaran yang bersifat unggulan, sebagai alternatif pemecahan masalah pendidikan di Indonesia.

Berdasarkan pada deskripsi di atas, menjadikan warga masyarakat desa kalibening yang berada di kaki gunung merbabu

melakukan perenungan serius atas berbagai kasus kolektif yang menimpa sebagian besar anak mereka yang tidak mampu melanjutkan ke jenjang pendidikan berikutnya alasan biaya. Disamping itu juga, sebagian besar masyarakat memiliki pemahaman yang sama bahwa untuk menjadi manusia yang pintar, cerdas dan bermanfaat tidaklah harus mendasarkan dan bersandar pada sekolah. Terlebih lagi dengan melihat fenomena semakin pudarnya ikatan emosional terhadap kultur masyarakat. Sementara, akar masyarakat merupakan norma yang terhitung fundamental (Musa, 2006 : 11).

Oleh karena itu, berawal dari paguyuban petani desa yang memiliki keresahan yang sama itulah kemudian muncul gagasan untuk membuat sekolah berbasis masyarakat yang menurut Naswil Idris, salah seorang pakar Diknas Indonesia, mengatakan bahwa SMP Alternatif Qaryah Thayyibah di Kalibening Salatiga Jawa Tengah ini sejajar dengan Tujuh Intellegent Communities sebagai keajaiban dunia yang terpilih sebagai pengguna ICT terbaik di dunia tahun 2005, kampung Issy-Les Moulienauk di Perancis, 
ISSN: 1829-6750 Inovasi Kurikulum, Februari 2008, Thn. 5. Vol 5 Nomor: 1

Kecamatan Mitaka di Tokyo, Kecamatan Pirai di Brazil, sebuah kampung di Singapura, Kampung Sunderland di Inggris, Kota Tianjin di China, dan Kota Toronto di Canada (Musa, 2006 : 221-222).

\section{B. Pembahasan}

\section{Konsep Kurikulum Berbasis Masyarakat}

Dalam Undang-Undang No. 20 tahun 2003 pasal 55 telah ditentukan mengenai Pendidikan Berbasis Masyarakat, sebagai berikut :

(1) Masyarakat berhak menyelenggarakan pendidikan berbasis masyarakat pada pendidikan formal dan nonformal sesuai dengan kekhasan agama, lingkungan sosial, dan budaya untuk kepentingan masyarakat.

(2) Penyelenggara pendidikan berbasis masyarakat

mengembangkan dan melaksanakan

kurikulum dan evaluasi pendidikan, serta manajemen dan pendanaannya sesuai dengan standar nasional pendidikan.

(3) Dana penyelenggaraan pendidikan berbasis masyarakat dapat bersumber dari penyelenggara, masyarakat, Pemerintah, pemerintah daerah dan/atau sumber lain yang tidak bertentangan dengan peraturan perundangundangan yang berlaku.

(4) Lembaga pendidikan berbasis masyarakat dapat memperoleh bantuan teknis, subsidi dana, dan sumber daya lain secara adil dan merata dari Pemerintah dan/atau pemerintah daerah. 
ISSN: 1829-6750 Inovasi Kurikulum, Februari 2008, Thn. 5. Vol 5 Nomor: 1

(5) Ketentuan mengenai peran serta masyarakat sebagaimana dimaksud pada ayat (1), ayat (2), ayat (3), dan ayat (4) diatur lebih lanjut dengan peraturan pemerintah.

Menurut Hamalik (2006 : 131), kurikulum berbasis masyarakat yang bahan kajiannya dan pelajarannya ditetapkan di daerah, disesuaikan dengan keadaan lingkungan alam, sosial, ekonomi, budaya serta kebutuhan pembangunan daerah yang perlu dipelajari oleh siswa daerah tersebut, guna memberikan kemungkinan pada mereka untuk akrab dengan lingkungannya dan juga agar mereka terhindar dari keterasingan lingkungannya. Tujuan dari kurikulum tersebut antara lain :

a. Memperkenalkan siswa terhadap

lingkungannya, ikut melestarikan budaya termasuk kerajinan keterampilan yang nilai ekonominya tinggi di daerah tersebut.

b. Membekali siswa kemampuan dan keterampilan yang dapat menjadi bekal hidup mereka di masyarakat, seandainya mereka tidak dapat melanjutkan ke jenjang pendidikan yang lebih tinggi.

c. Membekali siswa agar bisa hidup mandiri, serta dapat membantu orang tua dalam memenuhi kebutuhan hidupnya.
Karakteristik
Kurikulum Berbasis Masyarakat
Kurikulum berbasis masyarakat beberapa memiliki (Hamalik, 2006 : 132), antara lain :
a. Kurikulum
bersifat realistik, karena hal-hal yang dipelajari 
ISSN: 1829-6750 Inovasi Kurikulum, Februari 2008, Thn. 5. Vol 5 Nomor: 1

bersumber dari kehidupan nyata.

b. Kurikulum menumbuhkan

kerjasama dan integrasi antara sekolah dan masyarakat, karena sekolah masuk dalam masyarakat dan masyarakat masuk ke dalam lingkungan sekolah.

c. Kurikulum memberi kesempatan luas bagi siswa untuk melakukan belajar secara aktif (CBSA), yang dianjurkan oleh teori belajar modern. Para siswa merencanakan sendiri, mencari informasi sendiri, melakukan kegiatan proyek sendiri dan memecahkan berbagai masalah sendiri, baik melalui belajar individual maupun belajar kelompok.

d. Prosedur pengajaran memberdayakan semua

metode dan teknik pembelajaran secara sistematik dan bervariasi, seperti : ceramah, diskusi, kerja kelompok, dan sebagainya. Metodemetode mengajar ditata secara bervariasi dalam kerangka strategi pembelajaran karyawisata, manusia sumber, proyek, pelayanan masyarakat, survey dan sebagainya.

e. Kurikulum dilandasi konsep pendidikan "Education is here and now". Pendidikan adalah membantu siswa agar mampu berperan dalam kehidupan sekarang ini dan di sini. Sekarang ini, artinya hal-hal yang telah dipelajari berdayaguna untuk menghadapi tantangan yang ada dewasa ini. Di sini, berarti hasil pendidikan dapat diterapkan di 
ISSN: 1829-6750 Inovasi Kurikulum, Februari 2008, Thn. 5. Vol 5 Nomor: 1

masyarakat sekitarnya di mana mereka tinggal.

f. Kurikulum berbasis masyarakat

memberdayakan secara optimal semua sumber masyarakat untuk kepentingan pembelajaran

Masyarakat siswa. keseluruhan berbagai secara seperti : keluarga, pendidikan, teknologi, ekonomi, politik, rekreasi, budaya, sosial, dan dimensi kehidupan lainnya. Dimensidimensi tersebut masing-masing mengandung aspekaspek manusiawi, kelembagaan, sistem kehidupan, metode kerja, dan kondisisituasi dengan karakternya sendiri.

Komponen-komponen Kurikulum Berbasis Masyarakat
Oliva (Hamalik, $2006: 133$ ) menyatakan ada sejumlah komponen kurikulum yang saling berkaitan, ialah :

a. Tujuan dan filsafat pendidikan dan psikologi belajar

b. Analisis

kebutuhan masyarakat (mencakup sekitar siswa)

c. Tujuan kurikulum (TUK dan TKK)

d. Pengorganisasian dan implementasi kurikulum

e. Tujuan pengajaran (TIU dan TIK)

f. Strategi pembelajaran (mencakup model-model pengajaran)

g. Teknik evaluasi (seleksi awal dan seleksi final)

h. Implementasi strategi pembelajaran

i. Evaluasi (evaluasi pembelajaran) dan

j. Eveluasi program kurikulum 
ISSN: 1829-6750 Inovasi Kurikulum, Februari 2008, Thn. 5. Vol 5 Nomor: 1

Tahap-tahap Pengembangan Kurikulum Masyarakat

Menurut Hamalik (2006 : 134), ada duabelas langkah yang perlu dilaksanakan dalam pengembangan kurikulum, ialah :

Langkah 1: Penentuan tujuan pendidikan berlandaskan filsafat dan psikologi pendidikan berdasarkan spesifikasi kebutuhan masyarakat, kebutuhan siswa.

Langkah 2: Analisis kebutuhan (masyarakat sekitar kebutuhan siswa).

Langkah 3: Spesifikasi tujuan kurikulum (tujuan umum dan tujuan khusus).

Langkah 4: Idem dengan langkah 3.

Langkah 5: Pengorganisasian dan implementasi kurikulum dan struktur kurikulum.
Langkah 6: Spesifikasi tujuan pengajaran (TIU dan TIK).

Langkah 7: Idem dengan langkah 6 .

Langkah 8: Seleksi strategi (kegiatan, model, metode pengajaran)

Langkah 9: $\mathrm{A}=$ Seleksi awal teknik evaluasi

Langkah 9: B = Seleksi final teknik evaluasi (langkah ini dilakukan setelah langkah 5).

Langkah 10: Implementasi strategi pembelajaran aktual

Langkah 11: Evaluasi pengajaran (untuk menilai keberhasilan siswa dan efektifitas pengajaran dan perbaikan evaluasi).

Langkah 12: Evaluasi program kurikulum. 
ISSN: 1829-6750 Inovasi Kurikulum, Februari 2008, Thn. 5. Vol 5 Nomor: 1

\section{Konsep Pendidikan dan Sekolah Alternatif}

Sekolah alternatif memiliki banyak pengertian dan pemaknaan. Dengan adanya kata alternatif mengundang banyak penafsiran bagi orang yang ingin menerjemahkan. Namun dalam tinjauan ini akan disajikan beberapa penertian alternatif.

\section{Alternative}

Schools

Definition: This term broadly refers to public schools which are set up by states or school districts to serve populations of students who are not succeeding in the traditional public school environment. Alternative schools offer students who are failing academically or may have learning disabilities or behavioral problems an opportunity to achieve in a different setting. While there are many different kinds of alternative schools, they are often characterized by their flexible schedules, smaller teacher-student ratios and modified curricula. (http://michigan.gov/docume nts/Definition_of_Alt_70316 7._Ed.pdf, dikunjungi pada 5 April 2008).

Definisi di atas menyiratkan bahwa sekolah alternatif adalah sebuah istilah yang lebih luas mengacu pada sekolah umum yang diselenggarakan oleh negara atau daerah yang diperuntukkan bagi siswa yang tidak berhasil dalam menempuh pendidikan di lingkungan pendidikan umum tradisional.

Pendidikan alternatif adalah sebuah inisiatif dari sekolah di daerah yaitu sekolah yang dapat melahirkan ijasah pendidikan atau kerjasama lembaga pendidikan yang menyelenggarakan

pendidikan bagi siswa beresiko yang tidak mampu menyesuaikan dengan pola sekolah tradisional.

Pendidikan alternatif menggambarkan sejumlah pendekatan pengajaran dan 
ISSN: 1829-6750 Inovasi Kurikulum, Februari 2008, Thn. 5. Vol 5 Nomor: 1

pembelajaran dari pada sekolah tradisional. Pendekatan-pendekatan ini dapat diterapkan pada seluruh siswa pada segala umur, dari masa anak-anak sampai remaja, dan seluruh tingkat pendidikan.

Selanjutnya, menurut Wiki (2008) :

Alternative education, also known as non-traditional education or educational alternative, is a broad term which may be used to refer to all forms of education outside of traditional education (for all age groups and levels of education). This may include both forms of education designed for students with special needs (ranging from teenage pregnancy to intellectual disability) and forms of education designed for a general audience which employ educational and/or alternative philosophies (http://en.wikipedia.org/wiki/ Education, dikunjungi pada 5 April 2008).
Dalam definisi tersebut dinyatakan bahwa pendidikan alternatif juga dikenal dengan pendidikan non-tradisional yang mengacu pada pendidikan di luar pendidikan tradisional untuk seluruh kelompok dan tingkat pendidikan. Dalam hal ini termasuk dalam desain pendidikan yang berkebutuhan khusus dengan melandaskan pada filosofi dan metode alternatif.

Selanjutnya,

Mangun (Pradipto, 2007 : 65) tidak mengartikan pendidikan alternatif sebagai "mengganti sekolah formal", melainkan mencari materi dan metode didaktik baru-kurikulum baru. Mengingat bahwa dalam persekolahan telah kehilangan arti sejatinya karena hanya menjadi kelaskelas penataran. Sekolah menjadi ajang kompetisi, lomba ranking dan target prestasi sebagaimana diinginkan oleh dunia bisnis pembelajaran yang tidak adil. 
ISSN: 1829-6750 Inovasi Kurikulum, Februari 2008, Thn. 5. Vol 5 Nomor: 1

Visi, Misi, Strategi dan Aksi Pendidikan Alternatif di Indonesia

Djohar (Kompas : 2006 : 151-153) mengemukakan visi, misi, strategi dan aksi pendidikan alternatif di Indonesia sebagai berikut:

\section{Visi}

Berdasarkan kelemahan pendidikan kita saat ini, maka kita ingin menciptakan lingkungan pendidikan yang kondusif yang dapat menghasilkan pendidikan yang menyenangkan dan bermutu sehingga anak mampu membangun pribadi dan sosial budaya untuk mempersiapkan diri dalam mengadapi hidup pada masanya.

\section{Misi}

Misi pendidikan kita ingin:

a. Menciptakan lingkungan pendidikan yang kondusif

b. Mewujudkan pendidikan yang membangun pribadi yang mampu hidup mandiri

kebersamaan

masyarakat

c. Mewujudkan pendidikan yang mampu membangun manusia berperadaban dan berbudaya

d. Menciptakan pendidikan yang mampu mengendalikan emosional

e. Menciptakan pendidikan yang menumbuhkan skill kognitif, afektif dan psikomotorik.

f. Menciptakan pendidikan yang mengembangkan kreativitas

g. Menciptakan pendidikan yang mengembangkan multiple intelegensi

h. Mewujudkan pendidikan yang bermakna

i. Mewujudkan sistem pendidikan yang integratif 
ISSN: 1829-6750 Inovasi Kurikulum, Februari 2008, Thn. 5. Vol 5 Nomor: 1

\section{Strategi}

a. Menyelenggarakan pendidikan dengan kondisi lingkungan yang mendidik

b. Menyelenggarakan proses pembelajaran yang kontekstual dan berbasis lingkungan

c. Menyelenggarakan proses pembelajaran yang faktual dan konseptual

d. Menyelenggarakan pembelajaran yang membangun skill kognitif, efektif dan psikomotorik, menumbuhkan kreativitas, dan membangun kemampuan untuk pengendalian emosi

e. Menyelenggarakan pendidikan yang membangun fungsi hati

f. Memperbaiki sistem evaluasi pendidikan yang proporsional. g. Menyelenggarakan pendidikan terpadu antara pendidikan informal, nonformal dan formal

h. Menyelenggarakan pendidikan yang dapat mengembangkan multiinteligensi.

\section{Aksi}

a. Diciptakan lingkungan sekolah yang dapat mengembangkan diri anak

b. Guru menciptakan sistem pembelajaran yang mendidik

c. Guru menerjemahkan kurikulum dengan prosporsional

d. Guru mengorganisir bahan ajar yang fungsional

e. Guru menyiapkan objek atau persoalan belajar

f. Guru menciptakan interaksi belajar siswa yang fungsional 
ISSN: 1829-6750 Inovasi Kurikulum, Februari 2008, Thn. 5. Vol 5 Nomor: 1

g. Guru mengembangkan pembelajaran yang demokratis

h. Guru memonitor belajar siswa

i. Guru mengenali ciri karakteristik siswa

j. Guru memfasilitasi belajar siswa secara proporsional

k. Guru mengevaluasi secara proses-otentik melalui observasi

\section{Elemen Umum Sekolah Alternatif}

Beberapa elemen umum dalam sekolah alternatif adalah sebagai berikut (http://www.doe.mass.edu/alt ed/about.html?section=elem ents) :

Program pendidikan alternatif dapat dilaksanakan sebagai:

- Program afiliasi satu atau lebih sekolah-sekolah atau daerah

- Bagian dari sekolah alternatif induk
Tempat pendidikan alternatif :

- Bangunan-bangunan sekolah

- Komunitas atau pusat rekreasi

- Organisasi tetangga

- Lembaga komunitas

Komponen-komponen pendidikan alternatif :

- Pelayanan pembelajaran komunitas

- Intensitas monitoring akademik

- Partnership dengan lembaga lokal

- Pembelajaran kelompok kecil

- Pelatihan kecakapan hidup

- Pelatihan resolusi konflik

- Partenership dengan organisasi berbasis komunitas

- Kerja berbasis kesempatan belajar 
ISSN: 1829-6750 Inovasi Kurikulum, Februari 2008, Thn. 5. Vol 5 Nomor: 1

- Penjadwalan fleksibel

\section{Konsep SMP Alternatif Qaryah Thayyibah}

Konsep dikembangkan berangkat dari kenyataan yang ada, yang meliputi isu lokalitas, rumitnya birokrasi sekolah, persoalan waktu belajar, persoalan biaya, dan penjagaan mutu.

Kiranya konsep pilihan yang diterapkan SMP Alternatif Qaryah Thayyibah (http://www.pendidikanaltern atifsalatiga.com) adalah:

1. Lokalitas

Sekolah SMP alternatif ini dirancang dengan menggunakan kaidah lokalitas. Kaidah ini maksudnya bahwa komponen terpadu ( murid-murid/siswa, guru/tenaga pengajar, pengelola, pengurus / komite dan lokasi sekolah ) terwadahi dalam satu wilayah yang kira-kira dapat dijangkau dengan tidak capek berjalan kaki.
Maksud dari kaidah lokalitas ini adalah agar guru dan murid paham, mengetahui dan menyatu dengan persoalan sosial yang kurang lebih sama. Persoalan sosial yang sama akan mempermudah guru dan murid untuk belajar masalah sosial. Di satu sisi guru dengan mudah menerangkan masalah sosial dengan mengambil contoh-contoh. Di sisi lain murid akan dengan mudah pula memahami, meresapi dan bahkan mengkritik permasalahan yang diterangkan gurunya karena persoalan yang dihadapi sama.

2. Murah

SMP alternatif menawarkan sebuah konsep untuk memangkas beberapa pos pengeluaran para orang tua siswa sehingga biaya yang harus dikeluarkan bisa ditekan atau dialokasikan pada sesuatu yang memberi nilai dan manfaat lebih bagi kemajuan belajar. Dengan demikian konsep murah tidak 
ISSN: 1829-6750 Inovasi Kurikulum, Februari 2008, Thn. 5. Vol 5 Nomor: 1

bisa diartikan gratis atau cuma-cuma. Murah dimaksudkan sebagai upaya efisiensi beberapa hal yang sekiranya tidak perlu atau bisa digantikan dengan hal yang lain.

3. Memangkas birokrasi yang terlalu umit

SMP Alternatif menawarkan konsep birokrasi pendidikan yang memberdayakan siswa didiknya. Kegiatan dan membuat suatu karya adalah suatu keharusan sehingga kecerdasan dan ketrampilan anak didik terbangun. Yang membedakan disini adalah bahwa kegiatan dan karya itu lebih didasarkan pada kesepakatan, kebutuhan, dan persoalan yang riil dihadapi murid, orang tua, dan masyarakat dimana mereka tinggal. Dengan demikian, maka kegiatan, karya ataupun hal-hal lain yang dikerjakan tidak terpisah dari konteks kemasyarakatan lokalitasnya.
4. Efisiensi biaya dan waktu Masih berkaitan dengan konsep lokalitas ada konsep penting lainnya yang diajukan, yaitu dalam upaya memikirkan keberlanjutan pendidikan anak-anak. Biaya berkaitan dengan kemampuan orang tua dan keterjangkauan pendidikan itu sendiri, sedangkan waktu berkaitan dengan jarak yang harus ditempuh, ketepatan memulai dan mengakhiri pelajaranpelajaran, waktu efektif untuk pelajaran, dan stamina siswa.

Dalam hal efisiensi waktu tidak bisa lepas dari konteks lokalitas tadi. Anak-anak Kalibening sekitar pukul enam pagi sudah harus sudah ada di jalan untuk menunggu angkutan yang membawa mereka ke sekolahnya. Artinya, pukul enam pagi mereka sudah harus keluar dari rumah dan siap di jalan, menunggu kendaraan. Bila kesiangan resikonya adalah terlambat sampai di sekolah. Selain itu stamina murid 
ISSN: 1829-6750 Inovasi Kurikulum, Februari 2008, Thn. 5. Vol 5 Nomor: 1

sudah berkurang karena proses perjalanan.

\section{Penjagaan Mutu}

Mutu pendidikan merupakan hal yang harus diperhatikan. Pendidikan akan menjadi siasia bila mutu lulusannya rendah, tidak terbangun jiwa kemandirian

dan

kreatifitasnya, pada tataran berikutnya akan menambah beban masyarakat, keluarga dan negaranya. Hal ini mungkin terjadi karena orientasi nilai masih mendominasi pendidikan saat ini. Kecerdasan anak hanya diukur pada seberapa tinggi nilai yang diperoleh. Namun jiwa kemandirian, kreatifitas, keberanian berpikir nyaris luput dari perhatian. Maka tidak mengherankan bila lulusan dengan nilai tinggi dan juara kelas justru bingung dan tidak bisa apaapa ketika menghadapi realitas kehidupannya.

6. Partisipasi aktif orang tua / wali siswa
Telah disepakati bahwa tiap keluarga (kakak, orang tua/ wali) siswa mendapat kesempatan terlibat langsung dalam proses belajar mengajar di ruang berbeda sesuai mata pelajaran yang dikehendaki atau bagi yang memiliki

background pendidikan

memadai dianjurkan menjadi Guru Pamong serta Komite Sekolah. Tiap sebulan sekali mengadakan pertemuan rutin. Hal ini disamping untuk fungsi kontrol juga mengandung maksud untuk membangun kesatuan dan persatuan, senasib sepenanggungan.

\section{Pemberdayaan}

Mencermati kondisi sosial ekonomi orangtua/ wali siswa yang rata-rata dibawah garis standard kehidupan yang layak. Dalam pertemuan rutin, dirumuskan semacam asuransi yang sumbernya tidak mengurangi pos biaya lain. Melainkan membuat usaha produktif yang berprospektif ramah 
ISSN: 1829-6750 Inovasi Kurikulum, Februari 2008, Thn. 5. Vol 5 Nomor: 1

lingkungan guna peningkatan pendapatan. Misal

konglomerasi sektor

pertanian ( penguasaan bibit/ benih, budidaya, pengelolaan pasca panen, pemasaran).

\section{Profil SMP Alternatif Qaryah Thayyibah}

Dikatakan alternatif karena selama ini sistem pendidikan kita masih membelenggu, dingin, birokratis, dan tidak berpihak (terutama pada kaum miskin dan warga desa). Maka sebagai konsep tanding dari sistem tersebut Sekolah Menengah Pertama Qaryah Thayyibah (SMPQT) menawarkan

prinsip pendidikan alternatif sebagai berikut

Prinsip utama, pendidikan dilandasi

semangat membebaskan, dan semangat perubahan ke arah yang lebih baik. Membebaskan berarti keluar dari belenggu legal formalistik yang selama ini menjadikan pendidikan tidak kritis,dan tidak kreatif, sedangkan semangat perubahan lebih diartikan pada kesatuan belajar dan mengajar, siapa yang lebih tahu mengajari yang belum paham.

Prinsip kedua, keberpihakan, adalah ideologi pendidikan itu sendiri, dimana akses keluarga miskin berhak atas pendidikan dan memperoleh pengetahuan.

Prinsip ketiga, metodologi yang dibangun selalu berdasarkan kegembiraan murid dan guru dalam proses belajar mengajar, kegembiraan ini akan muncul apabila ruang sekat antara guru-murid tidak dibatasi, keduanya adalah tim, berproses secara partisipatif, guru sekedar fasilitator dalam meramu kurikulum.

Prinsip keempat, Mengutamakan prinsip partisipatif antara pengelola sekolah, guru, siswa, wali murid, masyarakat dan lingkungannya dalam merancang bangun sistem 
ISSN: 1829-6750 Inovasi Kurikulum, Februari 2008, Thn. 5. Vol 5 Nomor: 1

pendidikan yang sesuai kebutuhan.

(http://www.pendidikanaltern atifsalatiga.com, dikunjungi pada 20 Februari 2008):

Prinsip-prinsip inilah yang kemudian diturunkan dalam sebuah konsep pendidikan alternatif, bagaimana guru, pengelola, siswa, sarana penunjang dan lingkungannya saling berinteraksi:

\section{Guru}

1. Sebagai syarat utama pendidikan alternative, guru dan pengelola harus memiliki idealisme dan komitmen tinggi untuk selalu berpihak pada kemiskinan dan lingkungan.

2. Guru memahami metodologi pendidikan, punya kerangka berfikir yang terbuka.

3. Menguasai materi yang akan diajarkan, namun tetap menempatkan siswa sebagai tim yang secara bersama-sama berproses dalam belajar

4. Memahami analisis sosial, sehingga kebutuhan siswa dan masyarakat di lingkungan desanya terpenuhi

5. Memposisikan diri mengajar disertai belajar. Sehingga secara terus menerus memperbaiki kekurangan-kekurangan.

\section{Siswa}

1. Pemahaman bukan hapalan, mengetahui tidak sama dengan menelan pengetahuan mentah-mentah.

2. Kontekstual, sesuai kebutuhan, pemanfaatan lingkungan sebagai media belajar aktif, dialami sendiri dalam kesehariannya.

3. Muncul semangat kebersamaan di antara siswa, bagi yang nakal secara demokratis antar siswa sendiri yang memberikan hukuman, 
ISSN: 1829-6750 Inovasi Kurikulum, Februari 2008, Thn. 5. Vol 5 Nomor: 1

bukan guru. Bagi yang berprestasi secara bersama-sama disepakati diberi penghargaan, siapa yang tahu mengajari yang belum tahu, saling mengevaluasi antar siswa.

4. Kecerdasan siswa tidak hanya diukur dari nilai (kecerdasan intelektual), tetapi sejauh mana tingkat emosionalnya dan kecerdasan religinya.

5. Siswa selalu gembira sehingga akan muncul inovasi dan kreatifitas karena proses belajar tidak penuh tekanan.

\section{Sarana Penunjang}

Sarana penunjang pendidikan alternatif tidaklah mengharapkan gedung yang hebat, pagar tembok tinggi, seragam mewah, namun bagaimana seorang siswa berfikir global bertindak lokal. Di antara sarana yang diprioritaskan harus ada adalah:
1. IT (Informasi dan Teknologi), lebih spesifik adalah internet, seorang siswa akan menjelajahi pengetahuan tidak hanya sebatas buku paket, tapi ia akan lebih banyak memahami dan mencari pengetahuannya secara terbuka dan bebas.

2. Pemanfaatan lingkungan sebagai media belajar, siswa secara langsung bersentuhan dengan pertanian, home industri, konservasi alam, air, warung desa, dsb

3. Tokoh penggerak desa, ini menjadi penting karena dialah yang menjadi fasilitator sekaligus mediator bagi lembaga sekolah, masyarakat, pemerintah lokal, dan pihak-pihak lainnya yang terkait dengan sekolah.

\section{Institusi Sekolah}

Institusi sekolah dikelola dengan prinsip alam dan lingkungan sebagai laboratorium raksasa, arena 
ISSN: 1829-6750 Inovasi Kurikulum, Februari 2008, Thn. 5. Vol 5 Nomor: 1

hidup yang nyata, plural, terus berkembang dan berubah. Prinsip inilah yang menjadi pegangan agar lembaga sekolah selalu dinamis dan progresif dalam perjalanannya, tidak mandeg tetapi terus menyesuaikan perkembangan masyarakat.

SMP Alternatif merupakan lembaga pendidikan yang didirikan atas prakarsa masyarakat Kalibening, kemudian didukung beberapa orang luar yang faham realita baik sistem pendidikan formal maupun keresahan lain.

\section{Simpulan}

Desain kurikulum berbasis masyarakat di SMP Alternatif Qaryah Thayyibah dapat dusimpulkan sebagai berikut:

a) Menekankan pada keterlibatan masyarakat dalam proses pengembangan kurikulum. SMPQT tidak memposisikan siswa sebagai bagian yang terpisahkan

dari

masyarakat. Siswa adalah komunitas warga belajar sekaligus bagian dari masyarakat yang memiliki kebutuhan belajar. Sehingga siswa yang mengetahui akan kebutuhan-kebutuhan mereka dan siswa juga yang tahu bagaimana memenuhi kebutuhan mereka dengan aktiftas belajar.

b) Pengorganisasian komponen-komponen kurikulum dilakukan secara tentatif sejauh komponen-komponen tersebut bisa memenuhi kebutuhan siswa. Kebutuhan siswa yang paling utama adalah siswa dapat belajar dengan senang, nyaman, tidak terkekang, tidak memiliki rasa terpaksa atau dipaksa, dan menyadari bahwa pogram (kurikulum) tersebut sesuai dengan kebutuhannya. 
ISSN: 1829-6750 Inovasi Kurikulum, Februari 2008, Thn. 5. Vol 5 Nomor: 1

c) Desain kurikulum yang menyangkut fokus pengajaran di SMPQT terdiri dari tiga desain yaitu Subject Centered Design, Learner Centered Design, dan Problem Centered Design. Subject Centered Design lebih banyak dipelajari siswa kelas 1 karena masa transisi yang membutuhkan adaptasi dengan pembelajaran di SMPQT. Pada kelas 2 dan 3 subject centered design memiliki porsi kecil karena mereka lebih banyak mengambil program pilihan bebas. Program pilihan bebas ini merupakan

Learner

Centered Design dan Problem Centerd Design, yang ditentukan oleh siswa sendiri.

d) Desain kurikulum diorientasikan pada penumbuhkembangan kerjasama dan integrasi antara sekolah dan masyarakat, karena sekolah merupakan bagian dari masyarakat masuk ke dalam bagian lingkungan sekolah. Prinsip kebebasan yang diberikan kepada siswa menciptakan kesempatan luas bagi siswa untuk melakukan belajar secara aktif dan kreatif, yang dianjurkan oleh teori belajar modern.

e) Konsep kurikulum memberdayakan secara optimal semua sumber masyarakat untuk kepentingan

pembelajaran siswa. Masyarakat secara keseluruhan memiliki berbagai dimensi, seperti : keluarga, pendidikan, teknologi, ekonomi, politik, rekreasi, budaya, sosial, dan dimensi kehidupan lainnya. Dimensi-dimensi tersebut masing-masing mengandung aspek-aspek manusiawi, kelembagaan, sistem kehidupan, metode 
ISSN: 1829-6750 Inovasi Kurikulum, Februari 2008, Thn. 5. Vol 5 Nomor: 1

kerja, dan kondisi-situasi dengan karakternya sendiri.

Perencanaan

kurikulum berbasis masyarakat di SMP Alternatif Qaryah Thayyibah dapat disimpulkan sebagai berikut :

a) Keterlibatan masyarakat, wali siswa, dan seluruh civitas akademika SMPQT dalam pertemuan bulanan adalah satu bentuk need assessment/need analysis dalam menentukan komponen-komponen kurikulum. Perencanaan tujuan kurikulum berpijak pada kebutuhan masyarakat dan siswa. Dalam satu kelas bisa memiliki beberapa program yang berbeda yang memunculkan adanya beberapa kelompok belajar.

Masing-masing

kelompok belajar tersebut juga pada tahap selanjutnya akan menentukan materi kurikulum, pembelajaran proses evaluasinya.

b) Otonomi luas yang dimiliki siswa dalam merencanakan kurikulum adalah sebagai wujud bentuk demokratisasi dan pendewasaan dalam merancang bangun pendidikan bagi diri mereka.

c) Untuk kelas 2 dan 3, tujuan kurikulum yang mengacu pada subject matter dan program pilihan bebas memiliki perbandingan yang hampir sama, bahkan ada pogram pilihan bebas lebih banyak yang bisa mereka pilih. Bagi siswa kelas 3, pengambilan keputusan untuk subject matter biasanya dilakukan oleh siswa yang berkeinginan untuk memperdalam materi tersebut dan memiliki keinginan untuk mengikuti ujian formal (ujian semester atau ujian 
ISSN: 1829-6750 Inovasi Kurikulum, Februari 2008, Thn. 5. Vol 5 Nomor: 1

nasional) pada sekolah formal yang mendapat wewenang atau meminta soal pada dinas Diknas.

d) Perencanaan kurikulum di SMPQT juga diserahkan sepenuhnya pada masyarakat dan anak. Siswa tidak membuat target pencapaian tujuan yang terdaftar secara tertulis dalam tiap kali mereka akan melangsungkan pembelajaran.

Setiap proses yang berlangsung dalam pembelajaran (apapun jenis dan bentuknya), seluruhnya memuat nilai-nilai pendidikan yang harus dihargai. Bahkan ketika terdapat siswa yang diam di tengah-tengah proses pembelajaran di kelas, juga bagian dari belajar.

e) Perencanaan evaluasi direncanakan dan diputuskan secara bersama-sama di internal SMPQT. Evaluasi yang dilakukan oleh pengelola menyangkut faktor pendukung

penyelenggaraan

pendidikan seperti fasilitas, sarana dan prasarana pendidikan, sirkulasi keuangan dan kebijakan makro di internal SMPQT.

Pelaksanaan kurikulum berbasis masyarakat di SMP Alternatif Qaryah Thayyibah dapat disimpulkan sebagai berikut :

a) Siswa memiliki otonomi untuk melangsungkan proses pembelajaran yang mereka inginkan dengan tanpa menafikkan keterlibatan masyarakat dalam proses pembelajaran. Konsep pembelajaran yang berlangsung menggunakan pendekatan CTL (Contextual Teaching and Learning) dengan mendasarkan bahwa belajar harus dalam kondisi yang nyaman, menyenangkan, 
ISSN: 1829-6750 Inovasi Kurikulum, Februari 2008, Thn. 5. Vol 5 Nomor: 1

tidak terpaksa atau dipaksa, bisa dilakukan kapan saja dan dimana saja.

Langkah-langkah CTL di SMPQT adalah sebagai berikut:

- Langkah pertama yang dilakukan adalah siswa bersama guru mengobservasi suatu fenomena.

- Langkah kedua yang dilakukan adalah siswa bersama guru mencatat permasalahanpermasalahan yang muncul.

- Langkah ketiga adalah siswa secara bersamasama saling merangsang untuk berpikir kritis dalam memecahkan

permasalahan yang ada.

- Langkah keempat guru memotivasi siswa agar mereka berani bertanya, membuktikan asumsi dan mendengarkan pendapat yang berbeda dengan mereka.

b) Perencanaan pembelajaran tujuan mereka batasi tiap kali pertemuan. Prinsip yang dipegang adalah belajar tidak perlu dibatasi oleh target-target tertentu melainkan mengalir seperti air dan selalu berproses, begitu seterusnya. Oleh karena itu dinamika dan proses dialektika dalam pembelajaran tetap membuahkan pengetahuan-pengetahuan yang akan menjadi realitas pada diri siswa.

c)Perencanaan materi pembelajaran

berlangsung pada saat siswa hendak memulai proses pembelajaran atau pada pertemuan sebelumnya. Pemilihan materi pembelajaran bersifat dinamis, generatif dan multiinterdisipliner yang diambil dari berbagai macam sumber 
ISSN: 1829-6750 Inovasi Kurikulum, Februari 2008, Thn. 5. Vol 5 Nomor: 1

baik masyarakat, buku, koran, maupun internet. Pola pemilihan materi yang demikian memudahkan siswa dalam mengaitkan pengetahuan mereka yang sesungguhnya menjadi realitas bersama dalam kehidupan ini.

d) Sumber belajar bisa didapatkan dari masyarakat, buku, majalah, koran, internet dan masyarakat sekitar. SMPQT menekankan agar sumber belajar lebih banyak diadopsi dari masyarakat. Sumber belajar disesuaikan dengan materi belajar siswa. Bila materi belajar lebih banyak menyangkut aspek kognitif, maka sumber belajar lebih banyak memanfaatkan buku, majalah, koran dan internet.

e) Metode pembelajaran sangat bervariasi dan dinamis. Dalam satu kali pertamuan

bisa menggunakan metode yang bermacam-macam. Metode disesuaikan dengan materi yang sedang mereka pelajari sejauh metode yang digunakan bisa mendatangkan kesenangan dan kenyamanan dalam belajar.

f) Media belajar yang digunakan dalam proses pembelajaran juga sangat bervariasi dengan menyesuaikan pada materi dan tujuan pembelajaran mereka. Media yang tersedia seperti masyarakat, visual, audio dan audiovisual yang tersedia bisa digunakan siswa dalam proses pembelajaran mereka. Aset milik masyarakat yang bisa dimanfaatkan untuk pembelajaran juga digunakan, misalnya perkebunan, ladang, binatang ternak dan 
ISSN: 1829-6750 Inovasi Kurikulum, Februari 2008, Thn. 5. Vol 5 Nomor: 1

sebagainya

untuk

praktikum siswa.

g) Proses

pembelajaran siswa tidak selamanya berlangsung di dalam kelas. Siswa bisa belajar di mana saja sepanjang tempat itu bisa membuat siswa merasa nyaman dan senang dalam belajar. Pemilihan tempat belajar ditetapkan kapan saja sesuai keinginnan siswa.

h) Meskipun memiliki

organisasi

SMPQT struktur namun pola kerja yang dilakukan dan dikembangkan adalah dengan menggunakan pendekatan tim sebagai pilihan yang dinilai efektif. Dengan sebuah tim kerja, masing-masing anggota tim memiliki posisi yang sama untuk melakukan koordinasi pekerjaan yang lebih efektif.

Evaluasi Kurikulum Berbasis Masyarakat di SMP
Alternatif Qaryah Thayyibah dapat disimpulkan sebagai berikut :

a) Meletakkan dasar pada konsep kepuasan atas kebutuhan siswa selama belajar. Karena siswa yang belajar, maka siswa sendiri

yang mengukurnya. Sementara, kebutuhan siswa setiap saat bisa dikatakan bisa berkembang secara dinamis. Pihak SMPQT hanya berusaha memberi layanan dalam bentuk pendampingan yang dilakukan oleh guru / pendamping dan seluruh civitas akademika yang ada. Sebagai konsekuensi dari hal itu, maka pelayanan pihak SMPQT juga bersifat dinamis menyesuaikan diri dengan kebutuhan siswa.

b) Akibat dari kebutuhan siswa yang bersifat tentatif, menimbulkan konsekuensi pada kebutuhan waktu yang bersifat tentatif pula 
ISSN: 1829-6750 Inovasi Kurikulum, Februari 2008, Thn. 5. Vol 5 Nomor: 1

untuk melakukan

evaluasi. Hal ini

khususnya terjadi dalam melakukan evaluasi pembelajaran. Evaluasi tidak saja dilakukan pada saat setelah siswa melakukan proses belajar, tetapi juga selama proses itu terjadi.

c) Kegiatan evaluasi dilakukan oleh seluruh pihak SMPQT, termasuk masyarakat dan wali siswa. Pihak pengelola untuk tiap bulannya mengumpulkan orang tua siswa khususnya para siswa yang berdomisili di kalibening dan sekitarnya. Bagi wali siswa yang berasal dari tempat yang jauh, kadang hanya beberapa kali mengikuti pertemuan rutin tersebut.

d) Kadang para pendamping juga ikut andil dalam menentukan bentuk evaluasi bila program tersebut cenderung mengarah pada subject centered. Bila ada program yang lebih menekankan aspek kognitif, para siswa lebih sering menggunakan penyelesaian soal-soal dari buku dan internet sebagai instrumen evaluasinya. Di SMPQT tidak memiliki konsep evaluasi fromatif dan sumatif seperti sekolah formal.

e) Dalam akhir tahun pembelajaran, biasanya pihak SMPQT meminta siswa untuk membuat report atas pembelajaran yang mereka tempuh selama kurun waktu satu tahun terakhir. Report ini biasanya dikerjakan secara individu dalam bentuk hasil karya, dan bentuknya diserahkan pada siswa.

\section{Daftar Pustaka}

Ahmad, M. (2006). Pendidikan Alternatif Qaryah Thayyibah, 
ISSN: 1829-6750 Inovasi Kurikulum, Februari 2008, Thn. 5. Vol 5 Nomor: 1

Salatiga:

Yayasan

Qaryah Thayyibah.

Diknas. (2006). Rencana Strategis Direktorat Pendidik dan Tenaga Kependidikan

Pendidikan Nonformal. Jakarta: Dirjen PMPTP

Hamalik,

O.

(2006).

Manajemen

pengembangan

Kurikulum. Bandung :

PT Remaja Rosda Karya.

Hamalik,

O. (2006).

Implementasi Kurikulum,

Bandung: Sekolah Pasca Sarjana UPI Bandung.

Kompas. (2007). Kurikulum yang Mencerdaskan Visi 2030 dan Pendidikan Alternatif. Jakarta: PT. Kompas Media

Nusantara.

Michigan Department of Education, (2008). Here is a recommended definition Alternative Education programs. [Online]. http://michigan.gov/docu ments/Definition_of_Alt 70316_7._Ed.pdf [5
April 2008] Pradipto, D. (2007). Belajar Sejati versus Kurikulum Nasional. Yogyakarta: Penerbit Kanisius.

SMP Alternatif Qaryah Thayyibah. (2003). Konsep yang diajukan dalam SLTP Alternatif. [Online]. Tersedia: http://www.pendidikanalt ernatifsalatiga.com [20 Februari 2008].

SMP Alternatif Qaryah Thayyibah. (2003). Profil SLTP Alternatif. [Online]. Tersedia: http://www.pendidikanalt ernatifsalatiga.com [20 Februari 2008].

Sukmadinata, N.S. (2002). Pengembangan Kurikulum Teori dan Praktek. Bandung: PT. Remaja Rosda Karya.

Tersedia: 
ISSN: 1829-6750 Inovasi Kurikulum, Februari 2008, Thn. 5. Vol 5 Nomor: 1

Undang-Undang No. 20 tahun 2003 tentang Sisdiknas.

Untitled. (2008). Alternative Education. [Online]. Tersedia: http://www.k12academic s.com/alternative_educati on.htm, [5 April 12008]

Untitled. (2008). Education. [Online]. Tersedia: http://en.wikipedia.org/w iki/Education, [5 April 12008]

Untitled. (2008). Alternative Education. [Online].

Tersedia:

http://www.doe.mass.edu /alted/about.html?section =definition, 